\title{
Study on the Current Situation and Strategy of Marxism Theoretical Education in Colleges and Universities
}

\author{
Anbo Zheng ${ }^{1, \text { a }}$ \\ ${ }^{1}$ College of Automobile \& Civil Engineering, Beihua University, Jilin 132013, China. \\ aanbo_zheng@163.com
}

Keywords: Marxist theory, colleges and universities, education.

\begin{abstract}
The importance of the education of Marxist theory is elaborated from theoretical and practical aspect and analyzed the condition and problems of Marxism education in colleges and universities. Marxist theory of China education enlightenment is summarized through the comparison of the other socialist countries in Marxist education. The way both the positive and negative experience of other socialist countries' Marxist theory education are Initiated. Some countermeasures are put forwarded that how to solve the problems of Marxist theory education of domestic in the network information era.
\end{abstract}

\section{Introduction}

Since the founding of New China, the Marxist theory of education among Chinese universities in the final analysis is the ideological education. In daily life, and as long as the student mentioned ideologies, many people have conflicting emotions, that this is a forced to accept, often not necessarily the right ideas, is the sworn enemy of freedom of thought. But in fact, by no means the ideology of "patent" is not socialism "patent", but human class society in a long-term, widespread practice. In the presence of feudal society, capitalist society also exist. Ideological essence and purpose there are different classes of service for the class rule, even though each may differ in name and form. As in many Western countries do not necessarily have the name of ideology, but also plays a leading role ideology, but also stressed the unified guiding ideology, the ideology of the real name of a glance. For example, advertised "by the white" and "democracy" in the United States, to maintain its capitalist ideology single, first in 1919 forbid the University offers courses of Marxist theory, followed in early 1920, he launched a "white fear, decorated ": the United States Department of justice in the nation's 70 cities to start large-scale raids, arresting more than 10,000 propaganda, belief Communists Marxist theory. 1950 The US government has launched the infamous "long wheat tin cleansing" political persecution, simply because many people have been to China, they are subject to unwarranted "Communist agents" accusations and investigations.

The importance of Marxism as an ideology of dominance, it has just as Louis Althusser, "Ideology and Ideological State Apparatuses" described as: If any one class does not seize power while the ideological state the machine is placed and in which the exercise of white hegemony own, then his rule will not last long under its own control. He also Lenin, for example, pointed out that shortly after the October Revolution, Lenin raised proletarian power to make people, especially young people to give top priority to the task of proletarian ideological education. He did so with concern to rescue education (and other) ISAs revolutionary, its purpose is to make it possible to have seized state power of the Soviet proletariat services to safeguard the future of the dictatorship of the proletariat and to consolidate transition to socialism.

In addition, Althusser further noted in the book, the reproduction of the relations of production to a large extent depend on the ideological and political superstructure and to legal protection. Thus, for any state ideology shaken, actually trying to subvert this country, this country hinder the reproduction of the relations of production, disrupting the country's original order. April 2001, Jiang Zemin at the national conference on public order work, in the ideological field must always be to consolidate the guiding position of Marxism, a doctrine not East and West a doctrine, if the guiding ideology to engage in a wide variety, pluralism, then eventually to the ideological confusion and political turmoil 
in society. Thus, Marxism as an ideology in our country accounted for dominance, and its function in any one country. The ruling ideology, are reasonable proof of the ruling class regime legitimacy, cohesion of the people and maintain social good running order tool.

\section{College education of Marxist theory would construct the healthy growth and good critical society in China}

College education in Marxist theory as allow students to establish a Marxist beliefs, unified guiding ideology of an important part of the Communist Party of China has been the features and advantages, is also an objective reflection of socialist education laws. February 1, 2011, Comrade Jiang Zemin issued a "talk about educational issues," which clearly states that the principles of education must serve the socialist cause in our country's schools at all levels conscientiously implement the Education and Social Practice combination of education policy, in the reform and opening up and developing the socialist market economy, complex environment, adhere to the principle of this kind of education is extremely important. China's reform and opening up three decades, thought and culture at home and abroad collide with each other, mutual penetration, people's lifestyles, values, ways of thinking have a very big change. Non-Marxist world outlook and thoughts of many young students can not withstand the impact of all kinds, this effect exerts subtle influence inestimable to them, so that white liberalism, pluralism, the prevalence of money worship of great potential. Therefore, under the background of peaceful development and we must always be vigilant peaceful evolution.

Young students are the successors of the socialist cause with Chinese characteristics, among them quite a lot of people are the future of the Chinese Communist Party, is the main force of the Chinese nation revival of Albert, which is one of the major groups of Marxist theory of education. How many of them a correct outlook on life and values guide the ideological and political education and their ability to adapt to the healthy growth and good critical society, but also the key to defeat "peaceful evolution". Against this background, the university as a gathering place for young students, how to adhere to the Party's guiding ideology of unification, how to strengthen the College of education in Marxist theory to unite the younger generation, in order to create a united cohesion socialism with Chinese characteristics better tomorrow is an important issue, with a more prominent meaning.

In this regard, the Soviet Union provided us with a mirror. The Soviet Union in the 20th century 60-- 80s decades, ideological and political education for young serious mistakes, deal with the problem of young people thought too simple and extreme. Of '60s people', different sounds emitted by the strong repression of the 1980s, young people indulge in vain. "1960s" and there appeared "dissidents" and confused young people fall 1980s is that these practices consequences. "60's" and most believe that the Soviet Union will be better tomorrow, full of passion and full of bright emotions, hope for continuous social reform, but the Soviet authorities did not recognize the right of young people eager to reform this mood, not to the enthusiasm of young people to be a reasonable guide, but to suppress and persecute a large number of intellectuals and intellectuals, created a lot of miscarriages of justice. this pressure is also implicated in a lot of high school students, a number of youth organizations has also been identified as an error "anti-Soviet organization "was destroyed. The consequence is, an extremist faction - dissident group from the "60s" and in such a serious injury hit and split off, and the subsequent formation of a wave after wave of "dissident" movement. Looking back, in fact, was the so-called "dissident" movement there are many types, one of which is in the party and state institutions, principles and policies drawbacks criticism, but the heart still support the Soviet Communist Party and socialism of. So it is not "dissidents" in the strict sense. But the CPSU did not see this on the "dissidents" will be banned and repression, will worsen the problem. Until the 1980s, with the international exchange between the increasingly close, the majority of Soviet youth from the developed capitalist countries found their backwardness in general, coupled with the penetration by Western values, naturally sprouted in the heart of the CPSU and socialism faith suspicion or even offensive. On the other hand, when the CPSU did not take effective measures 
to deal with - there is no time to answer timely questions in mind young people through ideological work, but with isolation, and executive orders blocking the way to protect and nurture the so-called "pure socialism" ideology everything other than the culture of socialist culture negate; dramatically, as this method is not very effective, and under pressure from Western countries, the CPSU and go to the other extreme - the initiative to meet Western ideology, with Western values to transform Soviet society, the CPSU and the Soviet people to whom to give up years of goal, which push the country liberalism flooding. In this context, many young people become negative and pessimistic, spiritual emptiness, confusion and even a life of crime.

Visible, as Comrade Jiang Zemin profoundly pointed out: Marxist theory is to total thing, it will not learn ideological emptiness, spiritual poverty, amoral, in an unknown direction. In a socialist country, if you simply try to focus on the younger generation to develop their intellectual qualities, not for young students practical education in Marxist theory, any of its blind development or by any of its incitement and hostile forces control. So, the students trained in this guiding ideology, young students are likely to become spiritual emptiness, do not distinguish right and wrong, direction unknown persons, it is likely to become a knowledge society useless, or even harmful to society with knowledge people.

Therefore, the university education in Marxist theory work for China's development, the country's future competitiveness is crucial. Because it determines the ideological successor structure, knowledge structure, affecting their outlook on life, world outlook and political orientation. In the "CPC Central Committee and a number of resolutions on the strengthening of socialist spiritual civilization" clearly, to strengthen young people's ideological and moral education, is a relationship between the country's future, the fate of the big people. Types of schools should fully implement the Party's education policy, we must adhere to the socialist orientation, strengthen moral education to help young students lofty ideals, develop good moral character.

\section{College Marxist theoretical education Countermeasures}

In general, young college students aged mostly in the range of 18-20 years old, they inexperienced deep, is in the coming of age, to mature, to society in a transitional period, also is in the world, life and values gradually forming period, the psychological development is not yet fully mature, self-control is not strong, easy to move on. As China's reform and opening up a new generation of youth environment, they are passionate, but look at social problems lack of experience can easily be moved by emotional and ignore rational thinking, not heavy sense of truth; they are curious, eager to learn new things, willing to accept new things, rejection of the old activities, but easy to recognize extreme, committed "the eyes of all Western good heart without the slightest bit of good Chinese" error, that the Chinese culture is backward, right or wrong, is the West progress, right. Broaden their horizons, active thinking, like to pursue fashion, but easy to blindly follow the trend in the number of complex issues before it will exhibit naive or one-sided; they plasticity, proletarian communism heir hopes on the young students, while hostile forces but the "peaceful evolution" in hopes of young students.

Since the reform and opening up, economic tide concealing foreign culture strong impact on China's existing system of values, and the new common value standard has not yet been fully established, or have the necessary authority. Money worship, hedonism, extreme individualism and so much value orientation, the material tends to pursue serious, while ignoring the spiritual pursuit Correspondingly, the Marxist belief in the student population's influence has been shock, part Students ideology of Marxist theory of education to fade. Period of social transformation, the values of college students becoming diversified, the negative effects of the market economy to Marxist theory of education defined soil caused some negative impact, concentrated expression of the enjoyment of life too materialistic, too realistic goals in life, self-centered white the concept of strong, utilitarian heart strong, lack of integrity, social responsibility and so weak. Students lost a considerable part of the political direction and a direction in life that Marxist theory is slick, and not as good as the money came too important; Communism is the future, as current personal pleasure comes effectively; Marxist theory is the ruler of the service, better to seek personal future reliable. 
According to the survey, in the eyes of many students, the reality of life is of interest as well as the distribution of benefits of the relationship between people and combinations.

In the transition period, the institutional mechanisms and defects in the face, the face of liberalism, hedonism, money worship, extreme individualism eroded the face of social distribution is not perfect, the wealth gap between the poor and the interests of the people causing imbalances value departure. as well as the party of individual molecules abuse of power, corruption lawlessness severely damaged the party's image, the face of the corruption of the growth, spread, some people with suspected Marxist and socialist theory, criticism and even abandoned. These have weakened the party's cohesion and combat effectiveness, so that college students of Marxist theory Belief confusion, doubt, alienation negative impact.

\section{Summary}

The Ministry of Education pointed out the need to morality, teaching style construction as the focus, strengthen the construction of teachers, and continuously improve the ideological and political quality and professional quality of teachers. Teachers not only teach well, but also good people, all they have to set an example. To guide teachers to establish the correct values, quality and talent, enhance teaching, to the body social mission, to strengthen respect for the students, and care to students, protection of students' sense of responsibility. The old saying goes, "Germany for the division of the country, teachers are required," the teacher's words and deeds is always the students the best education, and for the Marxist theory of education workers, since Marxism involves belief, thus ethics division wind is the root of the Marxist theory of education. Specifically, the 'Ethics should start from the following aspects.

\section{References}

[1]Lin Bin: "On the Ideological and Political Theory Teaching Effectiveness of four power", "Ideological \& Theoretical Education", 20112.

[2]Flora Patterns Zhang Yixiang, Ren Rui: "The current way of life of the College Students and Ideological and Political Education", "Ideological \& Theoretical Education", 2011 first period.

[3]MAO: "Ideological and Political Theory Teaching Method Innovation Characteristics and Route", "Ideological \& Theoretical Education", 2011 first period.

[4]Zhang Nan: "Improving and innovative teaching methods and Improve Ideological and Political Theory Teaching Effectiveness", "Ideological \& Theoretical Education", 20112.

[5]CRITICAL: "Liu Shaoqi Marxist theory of education", "Hubei social science", in 2009 ninth period.

[6]Chai Xiaoxia, Zhang Erfang: "Marxist theory research and education institutions of higher learning principles," "Marxism", 20096.

[7]Zhao: "Enhancing spread from the perspective of Marxist theory of education effectiveness" and "ideological education", in December 2009 the first 12.

[8]Niu Yufeng, Huang Lifeng: "On the Education of Marxist Theory with Chinese Characteristics and Laws", "North China University of Technology (Social Science Edition)", in February 2009 the first one.

[9]Wei Ping: "On Improving the Effectiveness of the Marxist theory of education", "Economic Research Guide" 20096. 